\title{
Türkiye'de Öğretmenlerin Mesleki Gelişimi Nasıl Araştırılıyor?
}

\section{How Teachers' Professional Development was Examined in Turkey?}

\begin{tabular}{l}
\hline \\
\\
\\
Anahtar Kelimeler \\
Mesleki gelişim, \\
ögretmenlik mesleği, \\
ögretmen ögrenmesi, \\
lisansüstü tezler
\end{tabular}

\begin{abstract}
Raziye SANCAR ${ }^{1}$ Deniz ATAL ${ }^{2}$
\section{$\ddot{O}_{z e t}$}

Eğitim ve ögretim sürecinde istenilen hedeflere ulaşılabilmesi için öğretmenlerin
\end{abstract} bilgi, beceri ve yeterliklerinin sürekli gözden geçirilmesi ve süreç içinde mesleki gelişimlerinin desteklenmesi oldukça önemlidir. Alanyazında da ögretmenlerin mesleki gelişimleri pek çok araştırmaya konu olmuş ve çeşitli boyutlar ile ele alınmıştır. Yapılan araştırmada, ülkemizde ögretmen yetiştirme alanında yapılan ve öğretmenlerin mesleki gelişimine odaklanan lisansüstü tezler incelenerek öğretmenlerin mesleki gelişimlerine yönelik ne tür araştırmaların yapıldığına ilişkin bir çerçeve ortaya konulmak istenmiştir. Araştırmada nitel araştırma yöntemlerinden temel yorumlayıcı desen kullanılmış ve toplam 98 tez incelenmiştir. Belirlenen lisansüstü tezler; katılımcı türü, araştırma alanı, araştırma süresi, araştırma amacı ve araştırma yöntemi gibi boyutlar temel alınarak incelenmiştir. Ve ardından veriler iki ayrı araştırmacı tarafindan kodlanmıştır. Ardından incelenen kodlar arasındaki ilişkileri ve örüntüleri sunmak amacıyla VOSviewer programı kullanılmıştır. Araştırma sonuçlarına göre, ülkemizdeki lisansüstü tezlerde öğretmenlerin mesleki gelişimleri ele alırken çoğunlukla durum tespiti yapmak amacıla, sinırlı bir hedef kitle ile bir haftadan az sürede gerçekleşen uygulamalarla araştırma süreçleri yapılandırılmıştır. Ve araştırmaların büyük çoğunluğunda veriler süreç başında uygulanan anket ya da ölçekler ile toplanmıştır. Elde edilen bulgular ülkemizde mesleki gelişim araştırmalarındaki sınırlılıkları ortaya koyarken, ilerleyen süreçte öğretmenlerin mesleki gelişimlerinin derinlemesine uygulamalar, tekrarl ve çok boyutlu ölçümler ve süreç tasarımları, tartışmalar, iş-birlikleri, izlemeler, geri bildirimler, destekler, yaygınlaştırmalarla yürütülmesi gerektiğini göstermektedir.

\section{Abstract}

Considering the teachers' professional development, especially their knowledge, skills, and competencies are crucial to achieving the educational goals. The teachers' professional development has been constantly the focus of many studies with different perspectives in the literature. This study is aimed to reveal a framework for the research of teachers' professional development. For this reason, 98 postgraduate theses in the field of teacher training in Turkey are examined by employing a basic

Key Word

Professional development, teacher education, teacher learning, theses. interpretive design one of the qualitative research methods. The research data coded by the two researchers. Afterward, the VOSviewer program is used to present the relationships and patterns between the results. Based on the research results, it found out that the theses frequently carried out to determine the situation, taking place in less than a week, and with a limited number of participants. Moreover, it is seen that the theses data were mostly collected with a questionnaire or a scale at the beginning of the process. The findings underline some limitations of teachers' professional development studies in Turkey. In this regard, the teachers' professional development should implement through in-depth practices, repeated and multidimensional measurements, and process designs including discussions, collaborations, monitoring, feedback, support, and dissemination.

\begin{tabular}{|c|c|}
\hline $\begin{array}{l}\text { Atıf için: } \\
\text { For Citation }\end{array}$ & $\begin{array}{l}\text { Sancar, R., \& Atal, D. (2021). Türkiye’de öğretmenlerin mesleki gelişimi nasıl araştırıliyor? } \\
\text { Muğla Sıtkı Koçman Üniversitesi Eğitim Fakültesi [MSKU Journal of Education], 8(1), 339- } \\
\text { 354. DOI: 10.21666/muefd.847692 }\end{array}$ \\
\hline & Accepted: 09.04.2021 \\
\hline
\end{tabular}

\footnotetext{
${ }^{1}$ Ahi Evran Üniversitesi, Eğitim Fakültesi, raziye.sancar@ahievran.edu.tr ORCID: 0000-0002-2875-9233

${ }^{2}$ Ankara Üniversitesi, Eğitim Bilimleri Fakültesi, atal@ankara.edu.tr ORCID:0000-0001-8030-9996
} 
Öğretmen öğrenmesi, başka bir söyleyişle mesleki gelişimi, sıklıkla öğretmenlerin öğretim süreciyle ilgili öğrenci başarısını artırmaya yönelik bilgi ve becerisi olarak ifade edilmektedir (Desimone, Porter, Garet, Yoon ve Birman, 2002; Desimone, 2009; Sutherland, Howard, \& Markauskaite, 2010; Timperley, Wilson, Barrar, \& Fung, 2007). Bu tanımlamalarda mesleki gelişimin, öğretmenlerin öğretim uygulamaları ve yaklaşımlarına uzmanlık kazandırma potansiyelinin öne çıkarıldığı belirtilebilir (Sutherland ve diğerleri, 2010). Bir başka tanımlamada ise, öğretmen mesleki gelişimi, öğretmenlerin öğrenmesi, öğrenmeyi nasıl öğrendikleri ve öğrencilerin öğrenimini desteklemek için bilgilerini pratikte nasıl uyguladıkları olarak ifade edilmektedir (Avalos, 2011). Alanyazın incelendiğinde, öncesinde pek çok farklı bakış açısı ve yaklaşımla mesleki gelişim tanımlamaları yapılmasına karşın, günümüzdeki tanımlamalarda öğretmenlerin sahip oldukları özellikleri ve öğrenmeleri öncelendiği görülmektedir. Örneğin, Korthagen, Kim ve Greene (2013) çalışmalarında mesleki gelişimi, bir öğretmenin sahip olduğu tüm bireysel ve öznel niteliklerini etkin kullanabilmesi, ideallerinin, inançlarının ve kimlik duygusunun gelişmesi, yetkinliklerini sürekli geliştirebilmesi ve bu nitelik ve yetkinlikleri bulunduğu çevre, okul ve sınıfa uyarlayabilmesi ile tüm bunlar arasında sürdürülebilir tutarlılığa ulaşabilmesi olarak tanımlamışlardır. Söz konusu tanımlamada öğretmenin bireysel öğrenme sürecinin öncelendiği dikkati çekmektedir.

Öğretmen öğrenmesi çok boyutlu bir öğrenme biçiminde ele alınabilir. Korthagen'e (2007) göre bu çok boyutlu öğrenme sürecinde bilişsel, duyuşsal ve motivasyonel davranış kaynakları iç içe geçmiş ve sosyal bir bağlama yerleştirilmiştir. Her bir öğretmen ve öğretim süreci özgün olduğundan, öğrenme süreçleri tasarlanırken bu durum göz önünde bulundurulması önemlidir (Neil ve Morgan, 2003; Glover ve Law, 2005). Alanyazında da öğretmen öğrenmesini desteklemek amacıyla çeşitli yollara başvurulduğu ve birbirinden farklı öğrenme süreçlerinin tasarlandığı dikkati çekmektedir. Örneğin, önceleri öğretmenlerin öğrenmesini desteklemek için kurslar, konferanslar, hizmet içi eğitimler tasarlanırken (Macià ve García, 2016; Mitchell, 2013); daha sonra işbirlikli ve yansıtıcı düşünmeye olanak tanıyan öğrenme ortamları, duruma ve bağlama özgü değişkenler uygulama süreçlerinde ön plana çıkmıştır (Desimone, 2011; Edwards, Sandoval ve McNamara, 2015; Gomez, Gomez, Rodela, Horton, Cunningham, \& Ambrocio, 2015; Wang, 2018). Postholm'a (2012) göre öğretmen öğrenmesini okulda çeşitli kurslara katılma, kendi öğretimleri üzerine düşünme ve meslektaşları ile işbirliği içinde olma, başkalarının öğretimini gözlemleme ve söz konusu öğretim süreçleri üzerine düşünme aracıllğı ile sağlamak olanaklıdır. Benzer biçimde Korthagen'e (2017) göre de öğretmen öğrenmesi en çok deneyimler üzerine düşünerek, bilinçli/kasıtlı yansıtma çalışmaları ile gerçekleşebilir.

Mesleki gelişim sürecinde tartışılan bir diğer boyut, kurumsal yapının ve işbirliğinin süreçte göz önünde bulundurulmasıdır. Örneğin, Lawrence ve Chong'a (2010) göre mesleki gelişim sürecinde öğretmenlerin öğrenmesi kurumsal ve durumsal faktörler göz önünde bulundurularak düzenlendiğinde mesleki gelişim sürecine yarar sağlayacaktır. Postholm'a, (2012) göre de okulda diğer öğretmenlerle ve okul idaresi ile işbirliği içinde gerçekleşen öğrenme, öğretmenlerin kendi öğretimlerini geliştirmeleri ve öğrencilerin öğrenmesine fayda sağlayabilmeleri için en iyi yoldur. Mesleki uygulamaları ve öğrenci sonuçlarını iyileştirmek ve sürdürülebilir okul temelli koşullar geliştirmek için öğretmenlerin öğrenmesi/mesleki gelişimi önemli ve etkileyici unsurdur (Timperley, Wilson, Barrar ve Fung, 2007). Başka bir deyişle, öğretmenlerin öğrenmesi dikkate alınmadığında, okuldaki değişimler ve yenilikler başarısızlıkla sonuçlanabilmektedir (Bakkenes, Vermunt ve Wubbels, 2010). Bu nedenle araştırmacıların, karar alıcıların ve uygulayıcıların öğretmenin öğrenmesini/mesleki gelişimini etkileyen etmenleri çok iyi analiz ederek, mesleki gelişim sürecini bu doğrultuda yapılandırmaları gerektiği söylenebilir.

Alanyazın incelendiğinde pek çok araştırmacının eğitimde niteliğin öğretmen niteliği ile koşutluk gösterdiği konusunda aynı fikirde olduğu görülmektedir (Bkn. Korthagen, 2017; Korthagen ve diğ., 2013; TsoTeTsi ve Mahlomaholo, 2013; Yoon, Duncan, Lee, Scarloss ve Shapley, 2007). Bu fikirle birlikte gerek uluslararası alanyazında, gerekse ülkemizde öğretmenlerin mesleki gelişimlerini desteklemek amacıyla çok çeşitli araştırmalar ve tezler yapılmakta, projeler yürütülmektedir (bkn. Canara ve Mirici, 2020; Çiğdemoğlu, Tekeli ve Köse, 2019; Eroğlu ve Özbek, 2020). Ancak, konu ile ilgili alanyazında yer alan çalışmaların birtakım sınılılıkları ve eksikliklerinin de olduğu düşünülmektedir. Örneğin DeMonte'ye (2013) göre öğretmenler için mesleki gelişim sürecinde yaşanan 
en büyük sorunlardan biri; uygulama sürecinden ve işleyişten, başka bir söyleyişle gerçek durum/bağlamdan uzak ve genellikle bir uzman tarafından bilgi aktarımına odaklanılan mesleki gelişim uygulamalarıdır. Ülkemizde de öğretmen öğrenmesine ve gerçek sınıf ve okul bağlamına odaklanmaktan uzak pek çok mesleki gelişim etkinliklerinden söz etmek olanaklıdır. Burada sözü geçen çalışmaları küçük bir alıntı biçiminde vermektense, durumu betimsel biçimde vermenin ileride yapılacak olan araştırmalara rehberlik edebileceği düşüncesi ile bir araştırma tasarlanmıştır. Alanyazına katkısı ve gelecekteki araştırmalara yön verebilirliği göz önünde bulundurulduğunda, konu ile ilgili lisansüstü tezlerin incelenmesine karar verilmiştir. Uluslararası alanyazında mesleki gelişim sürecinin karmaşık yapısı üzerine çalışmalar artarak devam ederken, Türkiye'de yürütülen lisansüstü tezlerde mesleki gelişim süreçlerinin nasıl yapılandırıldığını belirlemenin öğretmen mesleki gelişiminin Türkiye' deki yansımalarını görünür hale getireceği düşünülmektedir. Öte yandan, içinde olduğumuz dönemde öğretmenlerden var olan tüm eğitim-öğretim şablonlarından farklı bir süreç yürütmeleri beklenmekte, alınan politik kararlarda mesleki gelişim gündemine oldukça büyük yere verilmektedir. Türkiye'de yeni tasarımlanması planlanan ve uygulanmaya çalışılan pek çok karar söz konusu iken, mesleki gelişim süreçlerine başlanmadan durum tespiti yapmak ve yol haritası çıkarmak en temel gerekliliklerden biri olarak düşünülmektedir. Dolayısıyla tasarlanan bu araştırmada, öğretmen yetiştirme alanyazınındaki tezlerden yola çıkılarak durum tespiti ile Türkiye'de mesleki gelişim kavramının sınırları ve içeriği ortaya konmaya çalışılmaktadır. Bu amaç doğrultusunda, Türkiye'de yapılan lisansüstü çalışmalar incelenirken cevaplanmaya çalışılan araştırma sorularına aşağıda yer verilmiştir.

1. Araştırma sürecine dahil edilen katılımcıların özellikleri nelerdir?

2. Araştırma ne kadar sürede yürütülmüştür?

3. Araştırmalar hangi konu alanları merkeze alınarak yapılandırılmıştır?

4. Araştırma sürecinde hangi temel amaç/amaçlar ele alınmıştır?

5. Araştırma amaçları ile koşut biçimde hangi veri toplama araç ve yöntemlerinden yararlanılmıştır?

\section{Yöntem}

Araştırmada nitel araştırma yöntemlerinden temel yorumlayıcı desen kullanılmıştır. Tümevarımsal bir araştırma stratejisini benimseyen bu desende veriler arasındaki ilişkiler ve örüntüler ortaya konularak bir anlamın ya da fenomenin nasıl oluştuğunu anlamlandırılmak olanaklıdır (Merriam, 2009). Yapılan araştırmada da öğretmenlerin mesleki gelişimlerini temel alan lisansüstü tezlerin odaklarına, bağlamlarına ve yapılarına yönelik örüntüler derinlemesine incelendiğinden bu araştırma deseni kullanılmıştır. Araştırmanın verilerin toplanması sürecinde ise, doküman incelemesi yöntemi kullanılmıştır. Bu yöntemle araştırma problemi ile ilgili kaynaklar sistematik ve kapsamlı bir biçimde belirlenmekte, incelenmekte, yorumlanmakta ve değerlendirilmektedir. (Bowen, 2009). Bu doğrultuda Türkiye'de konuya ilişkin yapılan lisansüstü tez çalışmaları incelenerek, belirtilen araştırma tasarımı çerçevesinde değerlendirilmiştir.

\section{Araştırma Kapsamında İncelenen Lisansüstü Tez Çalış̧maları}

Araştırma kapsamında incelenen lisansüstü tezlere Yükseköğretim Kurulu Ulusal Tez Merkezi'nden erişilmiştir. Öncelikle herhangi bir yıl sınırlaması yapılmaksızın yayınlanan tezlerin başlıklarında "mesleki gelişim" anahtar kelimesi kullanılarak tarama yapılmış ve toplamda 112 lisansüstü teze ulaşılmıştır. Öğretmenlerin mesleki gelişimlerine odaklanan tezler incelenmek istendiğinden konusu "eğitim ve öğretim" olan tezler listelenmiştir. Bu listeye girmeyen 3 lisansüstü tezi araştırma kapsamından çıkarılmıştır. Son olarak, belirlenen tezler arasından Yükseköğretim Kurulu Ulusal Tez Merkezi tarafından erişime açık olan tezler listelenmiştir. Tüm bu sınırlamalar sonucunda toplamda 98 lisansüstü tez araştırmaya dâhil edilmiştir. Araştırma kapsamında incelenen lisansüstü tezlere ilişkin bilgiler Tablo 1'de görülmektedir. 
Tablo 1

Araştırma Kapsaminda Incelenen Tezler

\begin{tabular}{llllll}
\hline Tez Düzeyi & 2001-2005 yılı & 2006-2010 yılı & 2011-2015yılı & 2016-2020 yılı & Tezlerin Sayısı \\
\hline Y. Lisans & - & 2 & 27 & 32 & 61 \\
Doktora & 2 & 4 & 9 & 22 & 37 \\
Toplam & 2 & 6 & 36 & 54 & 98 \\
\hline
\end{tabular}

Tablo 1'e göre, incelenen tezlerin yaklaşık \%62'sini yüksek lisans tezleri oluşturmaktadır. 2001 yılından 2010 yılına kadar öğretmenlerin mesleki gelişimlerine odaklanan tezlerin sayısı oldukça sinırlıyken (\%16), 2011 yılından itibaren konu ile ilgili yapılan çalışmaların hız kazandığı gözlenmektedir. Söz konusu tezler arasında özellikle 2016 yılından sonra doktora tezlerinin sayıca arttığı da görülmektedir.

\section{Verilerin Çözümlenmesi}

Verilerin çözümlenmesi aşamasına başlamadan önce, araştırmacılar tarafindan tez inceleme formu oluşturulmuştur. $\mathrm{Bu}$ formda lisansüstü tezlerin hangi bağlamda inceleneceğine yönelik temalara yer verilerek bir çerçeve oluşturulmuştur. Öğretmenlerin mesleki gelişimine odaklanan araştırmalara ilişkin, bağlam, amaç, süreç, süre, katılımcı sayısı vb. özellikler bu temalardan bazılarını oluşturmaktadır. Araştırmanın çözümleme çerçevesinin hazırlanmasının ardından veriler iki ayrı araştırmacı tarafından kodlanmıştır. İlk tur kodlamanın ardından kodların düzenlenerek kategoriler oluşturulmuştur. Araştırmada kodlar arasındaki ilişkileri ve örüntüleri belirlemek ve kodların yoğunluğu ortaya koymak amacıyla VOSviewer programından yararlanılmıştır. Söz konusu program çözümlenen verilerin birbirleriyle olan ilişkilerine ilişkin haritalama yapmaya olanak tanıdığından ve karmaşık örüntü yapılarını ortaya çıkarmayı desteklediğinden dolayı tercih edilmiştir.

\section{Geçerlik ve Güvenirlik}

Nitel araştırmalarda geçerlik ve güvenirliği sağlamak için inandırıcılık, aktarılabilirlik, güvenilebilirlik ve onaylanabilirlik gibi ölçütler kullanılmaktadır (Lincoln ve Guba, 1985). Araştırma sürecinin belirtilen ölçütlere uygun bir biçimde gerçekleşmesi için birtakım düzenlemeler yapılmıştır. Öncelikle araştırmanın benzer ortamlara aktarılabilirliği ve güvenilebilirliğini sağlayabilmek için araştırma amacı yeterince açık bir biçimde belirtilmiş, bağlamı ve sürecine ilişkin tüm aşamalar ayrıntılı bir biçimde betimlenmiştir. Verilerin çözümlenmesi aşamasında iki araştırmacı bir araya gelerek farklı kategoriler ve temalar üzerinde tartışarak fikir birliğine varmışlar ve bulgulara son halini vermişlerdir. Ayrıca araştırma sürecinde bulgular açık ve anlaşılır bir biçimde sunulmaya çalış1lmıştır.

\section{Bulgular}

$\mathrm{Bu}$ bölümde, araştırma alanı, katılımcı türleri ve sayıları, araştırma süresi, amacı, kullanılan araştırma yöntemleri ve veri toplama araçlarına göre incelenen tezlere ilişkin bulgulara yer verilmiştir. Ancak belirtilen temalarla ilgili bulgular tek tek sunulmadan önce, verilerin çözümlenmesi sürecinde kullanılan kodların oluşturduğu örüntü ve yoğunluk sunulmak istenmiştir (Şekil 1).

Şekil 1'de de görüldüğ̈̈ gibi, mesleki gelişim odaklı lisansüstü tezlerde incelenen kodlar birbirleriyle çok karmaşık ilişkiler kurmuştur. Bu kodlar arasında dikkati en fazla; "yüksek lisans", "0-1 hafta", "süreç başındaki anket", "durum tespiti yapmak" biçiminde ifade edilen kodlar çekmektedir. Bu durum mesleki gelişim odaklı lisansüstü tezlerin çoğunlukla yüksek lisans tezi olduğunu, genellikle durum tespiti yapmak amacıyla gerçekleştiğini, yapılan uygulamanın bir haftadan fazla sürmediğini ve genellikle verilerin süreç başında uygulanan anketler aracılığı ile toplandığını göstermektedir. Öte yandan Şekil 1'de kodlar arasındaki ilişkilerin karmaşıklığı da dikkat çekmektedir. Özellikle yüksek lisans tezleri ile anket, sıfır-bir hafta, tarama araştırmaları arasındaki ilişki göze çarparken, doktora tezleri ile son görüşme, gözlem, video çözümleme, öğretim becerisini geliştirmek gibi kodların yoğun ilişkili olduğu görülmektedir. Bununla birlikte belirtilen bu kodlar dışında da farklı amaç ve süreçler çerçevesinde gerçekleştirilmiş araştırmaların da olduğu gözlenmiştir. Aşağıda sırası ile bunlara ilişkin bulgulara yer verilmektedir. 


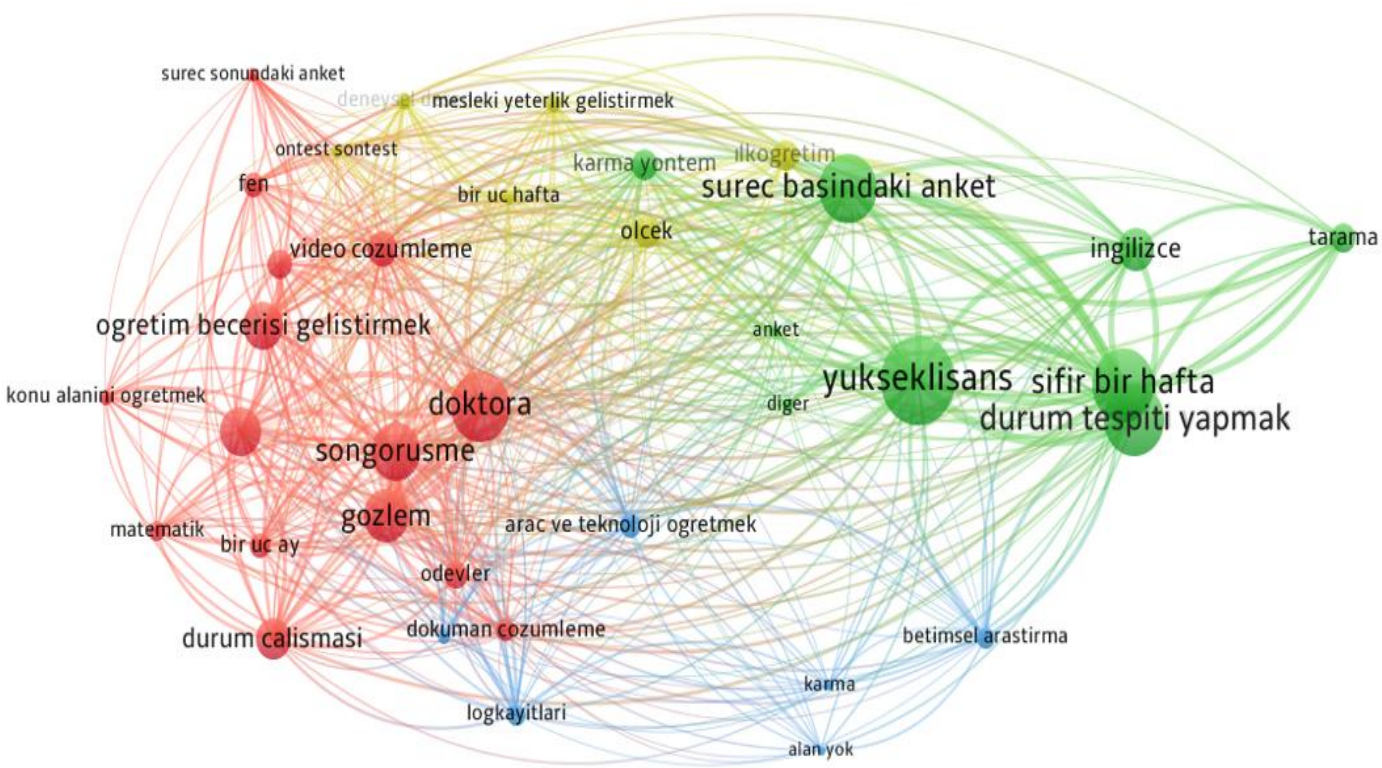

Şekil 1. Araştırmada Ele Alınan Tüm Kodların Birbiri ile İlişsisi ve Araştırmalardaki Yoğunlukları

\section{İncelenen Tezlerdeki Katılımcı Türleri ve Sayıları}

Yapılan lisansüstü tezlerdeki katılımcı türleri ve sayılarına ilişkin dağılım Tablo 2'de yer almaktadır.

Tablo 2

Tezlerdeki Katılımcı Türleri ve Sayıları

\begin{tabular}{|c|c|c|c|c|c|c|c|c|c|c|c|c|}
\hline & \multicolumn{2}{|c|}{ Öğretmen } & \multicolumn{2}{|c|}{ Öğrenci } & \multicolumn{2}{|c|}{$\begin{array}{l}\text { Okul } \\
\text { Yöneticisi }\end{array}$} & \multicolumn{2}{|c|}{$\begin{array}{l}\text { Öğretmen } \\
\text { Adayı }\end{array}$} & \multicolumn{2}{|c|}{$\begin{array}{l}\text { Öğretmen } \\
\text { Eğgitimcisi }\end{array}$} & \multicolumn{2}{|l|}{ Uzman } \\
\hline & f & $\%$ & $\mathbf{f}$ & $\%$ & $\mathbf{f}$ & $\%$ & $\mathbf{f}$ & $\%$ & $\mathbf{f}$ & $\%$ & $\mathbf{f}$ & $\%$ \\
\hline $1-10$ & 18 & 18,4 & 3 & 3,1 & 4 & 4,1 & 2 & 2,0 & 2 & 2,0 & 3 & 3,1 \\
\hline $11-50$ & 26 & 26,5 & 2 & 2,0 & 4 & 4,1 & 1 & 1,0 & 7 & 7,1 & 0 & 0,0 \\
\hline $51-100$ & 4 & 4,1 & 1 & 1,0 & 2 & 2,0 & 0 & 0,0 & 3 & 3,1 & 0 & 0,0 \\
\hline $101-200$ & 11 & 11,2 & 1 & 1,0 & 0 & 0,0 & 2 & 2,0 & 3 & 3,1 & 0 & 0,0 \\
\hline 201-500 & 14 & 14,3 & 1 & 1,0 & 0 & 0,0 & 0 & 0,0 & 0 & 0,0 & 0 & 0,0 \\
\hline 501 ve üzeri & 8 & 8,2 & 2 & 2,0 & 0 & 0,0 & 0 & 0,0 & 0 & 0,0 & 0 & 0,0 \\
\hline Toplam & 81 & $\mathbf{8 2 , 7}$ & 10 & 10,2 & 10 & 10,2 & 5 & 5,1 & 15 & 15,3 & 3 & 3,1 \\
\hline
\end{tabular}

Tablo 2 incelendiğinde en dikkat çekici bulgulardan birisi, araştırmaların çok önemli bir bölümünün $(\% 82,7)$ sadece öğretmenleri odağa alarak gerçekleşmiş olmasıdır. Katılımcı sayısına göre ise, araştırmaların \%26,5'inin, 11-50 öğretmenle; \%18'inin ise, 1-10 öğretmenle gerçekleştiği görülmektedir. 50'den fazla öğretmenle gerçekleşen araştırmaların sayısı ise, oldukça sınırlı olduğu görülmektedir. Örneğin 500'den fazla öğretmenle gerçekleşen araştırmaların sayısı yalnızca \%8'dir. Öğretmenlerden sonra tez çalışmalarında en fazla çalışlan örneklem grubu öğretmen eğitimcileridir, ancak bu kapsamdaki araştırmaların sayısının da sınırlı kaldığı görülmektedir $(\% 15,3)$. Öte yandan, alanyazındaki araştırmalarda etkili mesleki gelişim süreci için öğretmenler dışında önemi vurgulanan öğrenciler, okul yöneticileri, öğretmen adayları ve öğretmen eğitimcileri gibi diğer paydaşların araştırma süreçlerine yeterince dâhil edilmediği de söylenebilir. Örneğin, lisansüstü tezlerin yalnızca \%10,2'si öğrencileri ve okul yöneticilerini sürece katarken, öğretmen adayları ile yapılan araştırma sayısı yalnızca $\% 5,1$ 'i oluşturmaktadır. Tablo 2'de ortaya konulan bir diğer önemli bulgu ise, tez çalışmalarının hiçbirinde hükümet yetkililerinin örneklem grubuna dâhil edilmediği olup gerek politika yapıcılar gerekse idari yöneticilere araştırma sürecinde yer verilmediği görülmektedir. Dahası, yalnızca üç tez çalışmasının örneklem grubunda konu alanı uzmanlarına yer verdiği belirlenmiştir. 


\section{İncelenen Tezlerin Veri Toplama Süreleri}

Mesleki gelişim araştırmalarında tartışmaların süregeldiği bir diğer boyut araştırmaların süresi ile ilgilidir. Yapılan araştırmada lisansüstü tezlerinin veri toplama/uygulama sürelerine ilişkin bulgular Şekil 2'de yer almaktadır.

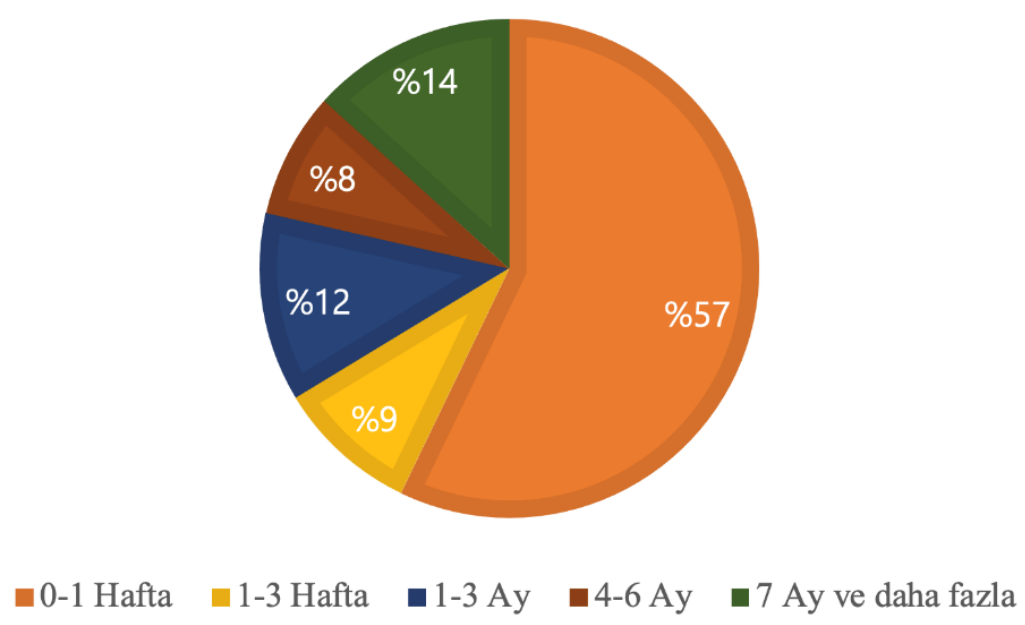

Şekil 2. Mesleki Gelişim Odaklı Lisansüstü Tezlerinin Veri Toplama Süreleri

Şekil 2'ye göre, incelenen tezlerin \%57'si bir haftadan daha az süre içinde gerçekleşmiştir. 1-3 hafta (\%9) ve 1-3 ay (\%12) aralığında süren tezlerin yüzdesi ise oldukça sınırlıdır. Mesleki gelişimin uzun bir süreç olduğu göz önünde bulundurulduğunda, 7 ay ve daha fazla sürede gerçekleştirilen araştırmaların sayısının ise sınırlı olduğu görülmektedir. (\%14).

\section{İncelenen Tezlerin Araştırma Alanları}

Araştırma bulgularına göre incelenen lisansüstü tezler çok farklı alanlarda gerçekleşmiştir. Şekil 3'de mesleki gelişim odaklı tezlerin konu alanlarına göre dağılımı yer almaktadır.

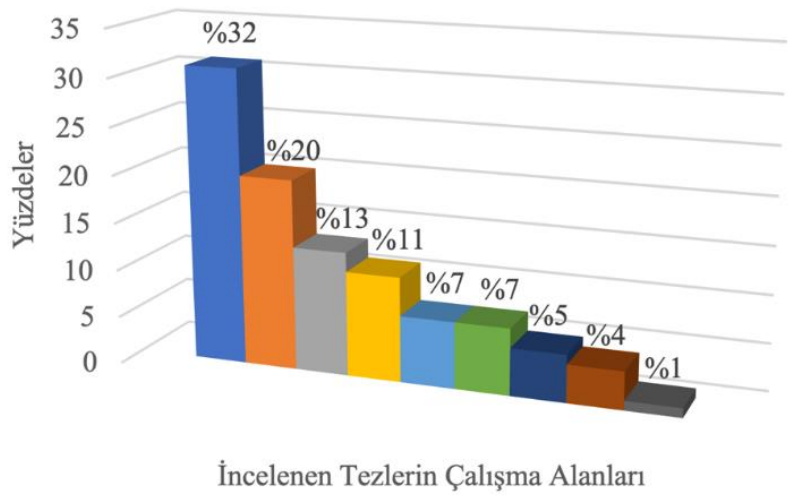

$$
\begin{aligned}
& \text { - İngilizce } \\
& \text { - İlköğretim } \\
& \text { = Fen } \\
& \text { = Matematik } \\
& \text { — Karma } \\
& \text { - Diğer } \\
& \text { - Belirtilmeyen } \\
& \text { - Okul Öncesi } \\
& \text { - Bilişim Tek }
\end{aligned}
$$

Şekil 3. İncelenen Tezlerin Alanlara Göre Dağılımı

Şekil 3'e göre, incelenen tezler çoğunlukla İngilizce (\%32), İlköğretim (\%20) ve Fen Bilimleri (\%13) alanında gerçekleştirilmiştir. Ayrıca, sayıları az olsa da Matematik (\%11), Okul Öncesi Eğitimi (\%4) ve Bilişim Teknolojileri (\%1) alanında da araştırmaların yapıldığı görülmektedir.

\section{İncelenen Tezlerin Amaçları}

Mesleki gelişimi konu alan lisansüstü tezlerin amaçlarının neler olduğunun ortaya konulmasının; araştırma sürecinin anlamlandırılabilmesi ve yapılan çalışmalardaki eğilimin ortaya konulabilmesi noktasında oldukça önemli olduğu düşünülmektedir. Buradan hareketle, yapılan tezlerin amaçlarının incelenmesi sonucunda elde edilen sonuçlar Şekil 4’te görülmektedir. 


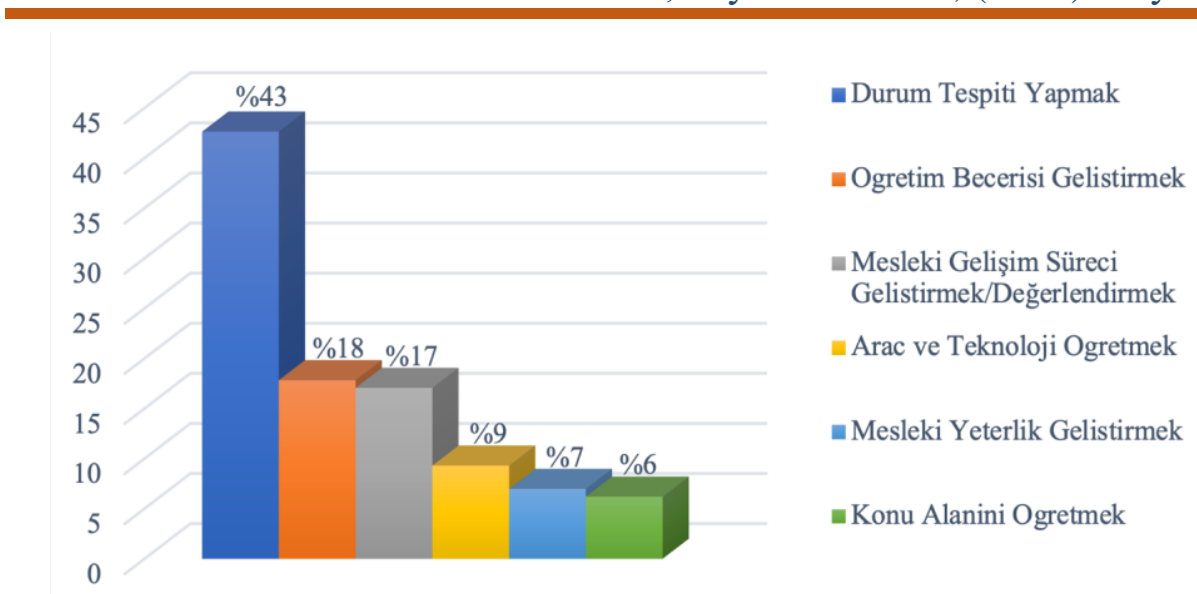

Şekil 4. İncelenen Tezlerin Araştırma Amacına Göre Dağılımı

Şekil 4'te görüldüğü gibi tezlerin \%43'ü durum tespiti yapmak amaciyla gerçekleştirildiği görülmektedir. Bunu sırasıyla, öğretim becerisini geliştirme (\%18) ve mesleki gelişim süreci geliştirme ve değerlendirme (\%17) izlemektedir. Yapılan araştırmalarda en az odaklanılan amaç ise, bir konu alanını öğretmenlere/öğretmen adaylarına öğretmek olduğu belirlenmiş̧ir (\%6).

Araştırmaların amacı ve süresi tek başına önemli olsa da, araştırma amacı ile süresi arasındaki ilişki de en az onlar kadar önemli olduğu düşünülmektedir. Örneğin, bir durum tespiti yapmak amaciyla planlanan araştırmanın süresi ile mesleki gelişim süreci tasarlamak, geliştirmek ve değerlendirmek amacıyla yapılan araştırmanın sürelerinin aynı olmaması beklenir. Tablo 3'te incelenen araştırmaların amacı ve süresi arasındaki ilişki yer almaktadır.

Tablo 3.

Incelenen Lisansüstü Tezlerinin Amaç ve Süre İlişkisi

\begin{tabular}{|c|c|c|c|c|c|c|c|}
\hline & 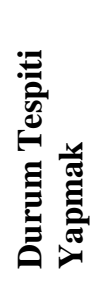 & 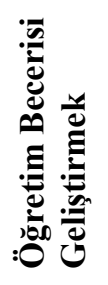 & & 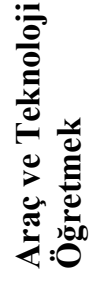 & 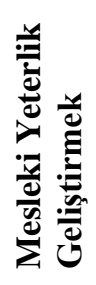 & 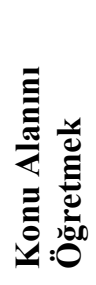 & $\frac{\Xi}{\stackrel{\Xi}{0}}$ \\
\hline 0-1 Hafta & 52 & 2 & $\overline{0}$ & $\overline{1}$ & 2 & $\overline{1}$ & 58 \\
\hline 1-3 Hafta & 1 & 5 & 1 & 3 & 2 & 0 & 12 \\
\hline 1-3 Ay & 1 & 4 & 7 & 2 & 2 & 1 & 17 \\
\hline 4-6 Ay & 1 & 4 & 4 & 3 & 1 & 2 & 15 \\
\hline 7 Ay ve fazlası & 0 & 8 & 10 & 3 & 2 & 4 & 27 \\
\hline Toplam & 55 & 23 & 22 & 12 & 9 & 8 & 129 \\
\hline
\end{tabular}

Tablo 3'e göre durum tespiti yapmayı amaçlayan çalışmaların neredeyse tamamına yakını 0-1 hafta arasında gerçekleşmiştir. Öğretim becerisi geliştirmeyi amaçlayan araştırmaların ise, zaman aralığı oldukça çeşitlidir. Tablo 3 incelendiğinde, bu çalışmaların 0-1 hafta gibi kısa bir sürede ya da 7 ay ve daha fazlası gibi uzun bir sürede gerçekleştiği görülmektedir. Tablo 3'teki dikkat çekici bulgulardan biri de mesleki gelişim süreci tasarlamak ve değerlendirmek amacıyla yapılan araştırmaların büyük bir kısmının, 3 aydan daha kısa sürede gerçekleşmiş olmasıdır. Bir diğer önemli bulgu da 1-3 hafta gibi oldukça kısa süreler içinde mesleki gelişim sürecinin tasarlanarak, uygulandığını ve değerlendirdiğini ortaya koyan tez çalışmalarının olmasıdır. Benzer biçimde 1 haftadan kısa sürede mesleki yeterlilik geliştirmeye odaklanan $(n=2)$ tez çalışmalarının da olduğu görülmektedir.

\section{Kullanılan Araştırma Yöntemi ve Veri Toplama Araçları}

İncelenen lisansüstü tezlerde kullanılan araştırma yöntemleri ve veri toplama araçları, bunların araştırmalardaki yoğunlukları Şekil 5'te yer almaktadır. 


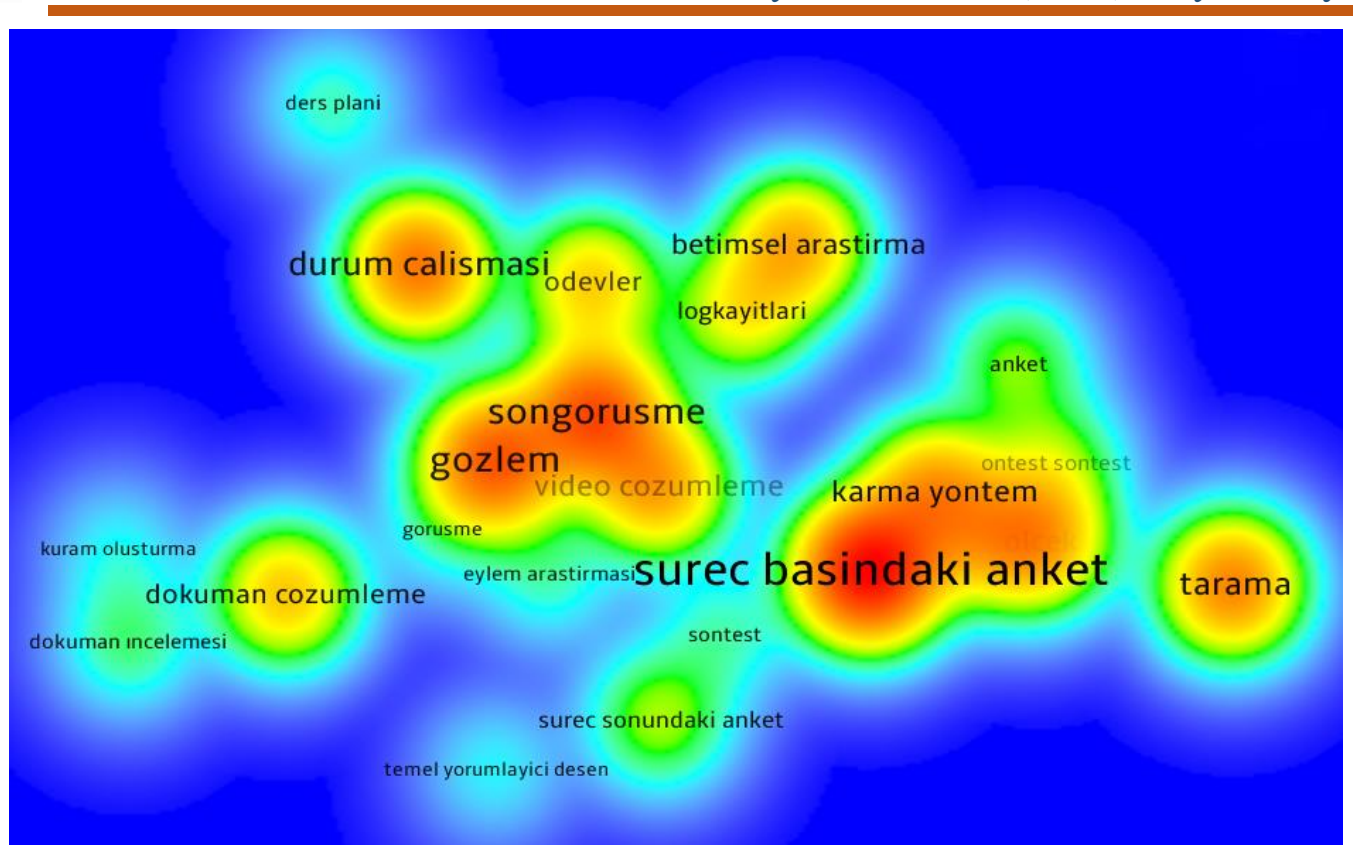

Şekil 5. İncelenen Tezlerde Kullanılan Araştırma Yöntemleri ve Veri Toplama Araçları

Şekil 5 yer alan yoğunluk haritasında, tez çalışmalarında yöntem olarak en fazla nitel (durum çalışması), nicel (tarama çalışması) ve karma yöntem kullanıldığı belirlenmiştir. Veri toplama aracı olarak da süreç başında uygulanan anket, gözlem, süreç sonunda yapılan görüşmelerin kullanıldığı görülmektedir. Her ne kadar eylem araştırması, doküman incelemesi ve kuram oluşturma gibi nitel araştırma yöntemlerinin kullanıldığı araştırmalar ve deneysel desenin kullanıldığı araştırmalar olsa da şekilde de açık bir biçimde görüldügü üzere söz konusu araştırma yöntemleri görece daha az yoğunluğa sahiptir. Tez çalışmalarında kullanılan veri toplama araçları için de benzer bir durum söz konusu olduğu görülmektedir. İncelenen tez çalışmalarında, ders planları ve ödevler, log kayıtları, öntest-sontestlerin uygulandığı araştırma süreçleri yürütülse de bu veri toplama araçlarını kullanan tez çalışmalarının sayısı oldukça sınırlı kalmıştır.

\section{Tartışma, Sonuç ve Öneriler}

Mesleki gelişim süreci, eğitim-öğretim sürecinin etkililiği, eğitim sisteminin niteliği ve dolayısıyla öğrencilerin başarısıyla doğrudan ilişkilidir (Avalos, 2011; Darling-Hammond, 2000; Desimone, 2009; Desimone ve diğerleri, 2002; Goe ve Stickler, 2008; Korthagen, 2017; Rockoff, 2004). Türkiye'de de özellikle son dönemde MEB politikalarında, Şura kararlarında, vizyon hedeflerinde ve strateji planlarında öğretmenlerin mesleki gelişimlerini etkili ve verimli kılabilmeye daha fazla odaklanıldığ 1 görülmektedir. Öte yandan, öğretmenlerin mesleki gelişimi konusu, akademinin de dikkati çekmiş ve özellikle son dönemde konuyu temel alan lisansüstü çalışmalar giderek artmıştır. Ancak araştırma bulgularında, ülkemizdeki lisansüstü tez çalışmalarında mesleki gelişim süreci genellikle tek bir boyutta ele alınmış, tüm boyutları ile derinlemesine yeterince incelenemediği görülmektedir. Örneğin, araştırma kapsamında incelenen tez çalışmalarının yarısından fazlasında durum ve gereksinim belirlenmiş; veri toplam sürecinde anketlerden yararlanılmış ve veriler bir haftadan daha kısa sürede toplanmıştır. Mesleki gelişim sürecinin çok boyutlu ve karmaşık bir süreç olduğu (Sancar, Atal ve Deryakulu, 2021) göz önünde bulundurulmamıştır.

Mesleki gelişim bağlamında yürütülen tez çalışmalarının sayıca artışını değerli bulmakla birlikte, ülkemizde öğretmenlerin mesleki gelişim süreçlerini desteklemek için yapılan araştırmalardaki temel sorunun; nicelikle yani araştırma sayısıyla ilgili olmaktan daha çok, konuya ilişkin çalışmaların niteliğiyle daha çok ilgili olduğu söylenebilir. Alanyazındaki pek çok araştırma da bu sonuçları desteklemekte (Arslan, 2013; Eyecisoy, 2014; Kulaz, 2013), nicelikten daha çok niteliğe odaklanan araştırmaların yapılması gerektiğini vurgulamaktadır (Günel ve Tanrıverdi, 2014). Bu noktada; özellikle planlama, uygulama ve değerlendirme süreçlerine odaklanan daha bütüncül ve derinlemesine süreç 
tasarımlarına gereksinim olduğu düşünülmektedir. Çünkü, bazı tez çalışmalarında mesleki gelişim sürecindeki eksikliğin en etkili biçimde nasıl giderilebileceğine ilişkin yeterli ve ayrıntılı bir süreç oluşturmadan yola çıkıldığı; araştırmalarda ele alınan mesleki gelişim sürecinin tüm boyutları düşünülmeden yalnızca uygulama ve değerlendirmeler yapılarak tamamlandığ 1 görülmektedir. $\mathrm{Bu}$ durumda ise, uygulama süreçlerinden ve eğitimlerden istenilen sonuçların alınabilmesinin güçleştiği görülmektedir. Bununla birlikte, uluslararası alanyazında durum bizim ülkemizden biraz daha farklı olduğu söylenebilir. Uluslararası alanyazında, mesleki gelişim odaklı çalışmaların durum tespiti yapmanın ötesine geçilerek daha çok mesleki gelişim programlarının etkililiğini değerlendirmek, öğretmenlerin değişim ve gelişimlerini izlemek, öğrenci başarısındaki değişime odaklanmak, teknoloji entegrasyonu/teknoloji destekli öğrenme ortamı sağlamak ve uygulama topluluğu oluşturmak/işbirlikli mesleki gelişim kültürü oluşturmak gibi amaçlara odaklanıldığı görülmektedir (Atal ve Sancar, 2021). Ve bu çalışmalarda öğretmenin davranışının çoğunun bilinçsizce üç boyut (bilişsel, duyuşsal ve motivasyonel boyutlar) tarafından yönlendirildiğini ve öğretmenin öğrenmesinin çeşitli düzeylerde gerçekleştiğini tartışılmaktadır (Korthagen, 2007). Artık ülkemizde de durum tespiti yapmanın ötesinde, farklı amaçlarla öğretmenlerin mesleki gelişimlerini desteklemeye, süreci geniş perspektifle incelemeye yönelik araştırmalar yapılabilir ve süreç birden fazla açıdan farklı boyutlarla düşünülerek yapılandırılabilir. Örneğin, planlanan bir mesleki gelişim sürecinde, öğretmenin bilişsel boyutu ile birlikte duyuşsal boyutuna da odaklanarak, ihtiyaç analizlerinin ötesinde, süreç yönetilirken elde edilen deneyimler izlenebilir, ara görüşmeler ve destek grupları oluşturularak derinlemesine çalışma ve değerlendirmeler yapılabilir.

$\mathrm{Bu}$ araştırmada göze çarpan bir diğer bulgu, araştırmaların süreleriyle ilgilidir. Araştırmalar, öğretmenlerin mesleki gelişimine ilişkin etkinliklerin belirli bir süre devam ettirilmesi gerektiğini, ancak bu tür etkinliklerin kapsamı ve süresi için net bir formül olmadığını ileri sürmektedir. Mesleki gelişim programlarının bir kısmının gerçek sınıf ortamından uzak, sürdürülmeyen, öğretmenlerin uygulamaları ve öğrencilerin öğrenmelerine üzerinde çok az etkisi olan, bir dizi tek seferlik etkinlikleri ve kısa süreli yüz yüze oturumları kapsadığı görülmektedir (Connelly ve James, 1998; Henderson, 2007). Söz konusu mesleki gelişim etkinlikleri görece yüzeysel uygulamaları içermekte olup, öğretmenlerin en iyi nasıl öğrenebilecekleri konusu göz ardı edilmektedir (Borko, 2004). Yapılan araştırma sonucunda da incelenen tezlerin büyük çoğunluğunun (\%57) yalnızca $0-1$ hafta süreyle yürütüldüğü belirlenmiştir. $\mathrm{Bu}$ durumun uluslararası alanyazın ile büyük ölçüde farklılaştığı görülmektedir. Uluslararası alanyazında mesleki gelişim bağlamında yürütülen araştırmaların yalnızca $\% 9,7$ 'sinin $0-7$ hafta sürdüğü belirlenmiştir (Atal ve Sancar, 2021). Benzer biçimde, Postholm (2012) öğretmen mesleki gelişimine ilişkin çalışmaları incelediği çalışmasında, yürütülen etkinliklerin süresinin genellikle bir dönemi ve 20 saatten iki yıla yayılan geliştirme faaliyetlerini kapsadığını belirlemiştir. Dahası, öğretmenlerin öğretim etkinliklerini değiştirmek ve geliştirmek için meslektaşları ile işbirliği yapmaya ve uygulamaları üzerinde daha fazla düşünmeye gereksinim duyduklarını ileri sürmüştür.

Uzun süreli etkinlikler etkin öğrenme için öğretmenlere daha fazla olanak sunmaktadır. Başka bir deyişle, uzun süreli mesleki gelişimle birlikte öğretmenler anlamlı tartışma, öğrenmeye daha etkin katılma ve günlük uygulamalarıyla daha kısa olanlara göre daha tutarlı bir biçimde bağlantı kurma olanağı bulabilmektedir (Birman ve diğerleri, 2000; Garet, Porter, Desimone, Birman ve Yoon, 2001). Quick, Holtzman ve Chaney'e (2009) göre, kalıcı bir değişimin sağlanabilmesi için en az üç ila beş yıla gereksinim duyulmaktadır. Öğretmenlerin yeni bir yenilikle ilgili kişisel kaygılardan öğrenci ihtiyaçlarını karşılamayı amaçlayan planlama, uygulama ve yönetim kaygılarına geçiş için genellikle birkaç ay hatta yıla ihtiyaç duyulmaktadır (Loucks-Horsley ve Stiegelbauer, 1991; akt. Kriek ve Grayson, 2009). Öte yandan, mesleki gelişim etkinliklerin türü ve kapsamı; uygulama süresini, mesleki gelişim için ayrılan süreyi ve maliyeti etkileyecektir (Garet ve diğerleri, 2001). Araştırmacıların süreç başında tüm bu değişkenleri göz önünde bulundurarak uygulama süresini düzenlemesi ve etkinliklerini planlamas1 önemlidir. Örneğin, tasarlanan mesleki gelişim sürecinde etkin öğrenmelerin gerçekleşebilmesi için; gözlenmek ve gözlemlemek, yeni materyal ve yöntemleri planlamak ve uygulamak, öğrenci çalışmalarını incelemek ve gözden geçirmek, sunum yapmak, tartışmalara liderlik etmek ve yazılı çalışmalar üretmek gibi olanaklar sunulabilir. Böylece mesleki gelişim etkinlikleri daha 
uzun süreli ve kapsamlı biçimde gerçekleştirilebilir. Öğretmen öğrenmesi, değişimi ve nihayetinde öğrenci öğrenmesi arasındaki ilişkilere odaklanan uzun soluklu boylamsal araştırmalar yürütülebilir.

Mesleki gelişim etkinlikleri tasarlanırken odaklanılması gereken temel nokta; öğrencilerin öğrenmesinin en iyi nasıl destekleneceği olması gerekir (Antoniou ve Kyriakides, 2013; Armour ve Yelling, 2004; Higgins ve Parsons, 2009; de Groot-Reuvekamp, Ros ve van Boxtel, 2018). Darling-Hammond, Hyler ve Gardner'a (2017) göre, etkili mesleki gelişim etkinliklerinin, öğretmenlerin sınıf-içi uygulamalarındaki değişikliklere ve öğrencilerin öğrenme çıktılarındaki iyileşmelere etki etmesi gerekir. $\mathrm{Bu}$ nedenle, öğretmenlerin mesleki gelişim süreçlerini değerlendirirken öğrencilerin başarılarındaki ve öğrenme çıktılarındaki değişikliğin göz önünde bulundurulması oldukça önemlidir. Ancak, incelenen tez çalışmalarında öğretmenlerle birlikte öğrenciler başta olmak üzere sürece etki eden paydaşlara yeterince odaklanılmadığı belirlenmiştir. İncelenen tezlerin yaklaşık \%80'i öğretmenler sürece katılırken; mesleki gelişim sürecinin temelinde yer alan öğrencilere yer verilen tez çalışmalarının oranı \%10 ile sınırlı kalmıştır. Dahası, incelenen tez çalışmalarının katılımcıları küçük örneklemlerle sinırlı kaldığı görülmüştür.

Mesleki gelişim sürecinde okul bağlamı ve meslektaşlarla işbiriliğinin yeri ve önemi açık bir biçimde ifade edilirken (Sancar ve diğerleri, 2021); incelenen tez çalışmalarında okul yöneticilerine, hükümet yetkililerine, karar alıcılara ve öğretmen eğitimcilerine de yeterince yer verilmediği görülmektedir. Öğretmen eğitimcilerinin, başka bir söyleyişle alan uzmanlarının sahip oldukları derinlemesine bilginin uygulamaya aktarılması, öğretmenlerle paylaşılarak mesleki gelişim etkinliklerinin desteklenmesi önemlidir (Bkn. Cobb, Zhao ve Dean, 2009; James ve McCormick 2009; Keung 2009; Opfer ve Pedder 2011; Postholm 2012; Sancar ve diğerleri, 2021; Sales, Traver ve García, 2011; Timperley ve diğerleri, 2007). Ancak gerek Türkiye'de gerekse uluslararası alanyazında mesleki gelişim sürecine tüm paydaşların etkin yer almıyor ve uygun işbirlikleri geliştirilmiyor olması pek çok sorunu beraberinde getirmektedir. Evans'a (2014) göre, mevcut mesleki gelişim modelleri mesleki gelişimi bütüncül olarak incelemekte başarısızdır. Okul bağlamının mesleki gelişim sürecinde başlı başına bir etkiye sahip olduğunu vurgulayan Postholm'a (2012) göre araştırmaların daha gerçekçi bir bakış açısıyla yapılandırılması gerekir. Sancar ve meslektaşlarına (2021) göre, mesleki gelişim etkinlikleri tasarımlanırken yerel okul bağlamlarında çalışan öğretmenler değişim süreçlerinin başlangıç noktası olacağı göz önünde bulundurulmalıdır. Benzer biçimde, Atal ve Sancar (2021) araştırmalarında uluslararası alanyazındaki mesleki gelişim araştırmalarında da sıklıkla politikaların önemine değinilmesine karşın, hükümet yetkililerinin ve karar alıcılarının mesleki gelişim sürecine neredeyse hiç dahil edilmediğini ortaya koymuşlardır.

Korthagen'e (2007) göre öğretmen öğrenmesinin bilinçsiz, çok boyutlu ve seviyeli yapısı vardır ve mesleki gelişim süreci öğretmenlerin endişeleri, psikolojik özellikleri, kişisel olarak güçlü yanları ve misyonları üzerine inşa edilmelidir (Fullan, 2007). Guskey'e (2002) göre de mesleki gelişim sürecinde öğretmenlerin sınıf uygulamalarıyla birlikte tutum ve inançlarında da değişiklikler meydana getirmek önemlidir. Bu değişiklikler, mesleki gelişim sürecinin; uygulamalar, tekrarlar, tartışmalar, işbirlikleri, izlemeler, geri bildirimler, destekler ve yaygınlaştırma çalışmalarıyla desteklenmesine bağlıdır. Alanyazında bazı fikir ayrılıkları olsa da etkili mesleki gelişim uygulaması için sürekli ve sürdürülebilir, iş birliğine ve gönüllüğe dayalı, hem konu alanı hem de pedagoji bilgisine birlikte odaklanan ve uygulamalı bir süreç tasarımına odaklanan araştırmalar bulunmaktadır (Caena, 2011; Desimone, 2009; Korthagen ve diğ., 2013; Walter ve Briggs, 2012; Wei, Darling-Hammond, Andree, Richardson ve Orphanos, 2009). Burada önemli olan, herkes için tek ve doğru yol olmadığını göz önünde bulundurarak öğretmenlerin düşüncelerini, hislerini ve davranışlarını destekleyebilmektedir. Bunun için verilen eğitimlere ek olarak çevrimiçi ortamlar, çevrimiçi koçluk, öğrenme toplulukları geliştirilebilir, öğretmenlere daha fazla erişilebilir ve sürekli destek sağlanabilir. Böylece öğretmenlerin tüm boyutları ile desteklenebilmesi için olanaklar sunulmuş olacağı düşünülmektedir.

İyi bir öğretimin tesadüfen gelişmesi mümkün olmadığından, mesleki gelişim sürecinde, öğretmen ögrenmesine ve gelecekteki hedeflere bağlanmak; süreci politikalar, ulusal standartlar ve değerlendirmelerle uyumlu hale getirmek; meslektaşlarla iletişimi teşvik etmek için süreç tasarımları yapmaya odaklanmak son derece önemlidir (Darling Hammond ve McLaughlin, 1995). Korthagen'e 
(2007) göre öğretmenin öğrenmesi hakkında yeterli bilgi olmadan, kuram ve öğretim uygulamaları arasındaki bağı geliştirme girişimleri karanlıkta bir atıştan başka bir şey değildir. $\mathrm{Bu}$ nedenle tasrımlanacak mesleki gelişim süreçlerinde, öğretmenler ne düşünüyor, hissediyor, istiyor, idealleri neler, onlara neler ilham veriyor, ne tür öğretmenler olmak istiyorlar? Öğretmenlerin potansiyelleri nedir? gibi soruların göz önünde bulundurulması gerektiği düşünülmektedir. Yüksek nitelikli etkinlikler tasarlamanın ve uygulamanın süreç olarak uzunluğu, maliyeti ve zorluğu düşünüldüğünde sürecin pek kolay olmayacağı açıktır. Ancak en iyi mesleki gelişim uygulamalarının özelliklerinin tartışılageldiği günümüzde; uygulama süresine, çok yönlü katılıma, bağlam ve uygulama odaklılığa dolayısı ile en çok da öğretmen öğrenmesine daha fazla odaklanmanın gerektiği düşünülmektedir.

\section{Kaynakça}

Antoniou, P., \& Kyriakides, L. (2013). A dynamic integrated approach to teacher professional development: Impact and sustainability of the effects on improving teacher behaviour and student outcomes. Teaching and Teacher Education, 29 (1), 1-12. https://doi.org/10.1016/j.tate.2012.08.001

Armour, K. M., \& Yelling, M. R. (2004). Continuing professional development for experienced physical education teachers: Towards effective provision. Sport, Education and Society, 9(1), 95-114. https://doi.org/10.1080/1357332042000175836

Arslan, H. (2013). Hizmetiçi eğitim kurslarının bilişsim teknolojileri öğretmenlerinin mesleki ve kişisel gelişimine etkisi. (Yayınlanmamış yüksek lisans tezi). Necmettin Erbakan Üniversitesi Eğitim Bilimleri Enstitüsü, Konya.

Atal, D., \& Sancar, R. (2021). Öğretmenlerin mesleki gelişimlerine odaklanan araştırmalar ne söylüyor? Erzincan Üniversitesi Ë̆itim Fakültesi Dergisi, 23(1).

Avalos, B. (2011). Teacher professional development in Teaching and Teacher Education over ten years. Teaching and Teacher Education, 27(1), 10-20. https://doi.org/10.1016/j.tate.2010.08.007

Bakkenes, I., Vermunt, J. D., \& Wubbels, T. (2010). Teacher learning in the context of educational innovation: Learning activities and learning outcomes of experienced teachers. Learning and Instruction, 20(6), 533-548. https://doi.org/10.1016/j.learninstruc.2009.09.001

Birman, B. F., Desimone, L., Porter, A. C., \& Garet, M. S. (2000). Designing professional development that works. Educational Leadership, 57(8), 28-33.

Borko, H. (2004). Professional development and teacher learning: Mapping the terrain. Educational Researcher, 33(8), 3-15. https://doi.org/10.3102/0013189X033008003

Bowen, G. A. (2009). Document analysis as a qualitative research method. Qualitative Research Journal, 9(2), 27-40. https://doi.org/10.3316/QRJ090202

Caena, F. (2011). Literature reviev quality in teachers' continuing professional development. European Commission Directorate-General for Education and Culture. https://ec.europa.eu/assets/eac/education/experts-groups/2011-2013/teacher/teachercompetences_en.pdf adresinden 19.08.2020 tarihinde erişilmiştir.

Canaran, Ö., \& Mirici, İ. H. (2020). Öğretmenlerin mesleki gelişimi için yeni bir takım öğretimi modeli: Hizmet-içi İngilizce öğretmenleri üzerine bir durum çalışması. Eğitim ve Bilim, 45(201), 247271. http://doi.org/10.15390/EB.2020.8430

Cobb, P., Zhao, Q., \& Dean, C. (2009). Conducting design experiments to support teachers' learning: A reflection from the field. The Journal of the Learning Sciences, 18(2), 165-199. https://doi.org/10.1080/10508400902797933

Collinson, V., Kozina, E., Kate Lin, Y. H., Ling, L., Matheson, I., Newcombe, L., \& Zogla, I. (2009). Professional development for teachers: A world of change. European Journal of Teacher Education, 32(1), 3-19. https://doi.org/10.1080/02619760802553022 
Connelly, U., \& James, C. (1998). Managing the school improvement journey: The role of continuing professional development. Journal of In-Service Education, 24, 271282. https://doi.org/10.1080/13674589800200042

Çiğgdemoğlu, C., Tekeli, A., \& Köse, F. (2019). Okul-dışı öğrenmeye yönelik öğretmen mesleki gelişim programından mentorlük desteği alan öğretmenin öğrencilerine yansıyan etkileri-Bir örnek olay çalışmasıs. Kastamonu Eğitim Dergisi, 27(5), 2311-2330. https://doi.org/10.24106/kefdergi.3521

Darling-Hammond, L. (2000). Teacher quality and student achievement: a review of state policy evidence. Education Policy Analysis Archives. 8(1), 1-44.

Darling-Hammond, L., \& McLaughlin, M. W. (1995). Policies that support professional development in an era of reform. Phi Delta Kappan, 76(8), 597-604. https://doi.org/10.1177/003172171109200622

Darling-Hammond, L., Hyler, M. E., \& Gardner, M. (2017). Effective teacher professional development. Palo, Alto, CA: Learning Policy Institute.

de Groot-Reuvekamp, M., Ros, A., \& van Boxtel, C. (2018). A successful professional development program in history: What matters? Teaching and Teacher Education, 75, 290-301. https://doi.org/10.1016/j.tate.2018.07.005

DeMonte, J. (2013). High-quality professional development for teachers: supporting teacher training to improve student learning. Center for American Progress, http://www.tapsystem.org/publications/tap-in-focus-center-for-american-progress-highquality-teacher-professional-development.pdf. adresinden 16.06.2020 tarihinde erişilmiştir.

Desimone, L. M. (2009). Improving impact studies of teachers' professional development: Toward better conceptualizations and measures. Educational Researcher, 38(3), 181-199. https://doi.org/10.3102/0013189X08331140

Desimone, L. M. (2011). A primer on effective professional development. Phi Delta Kappan, 92(6), 6871. https://doi.org/10.1177/003172171109200616

Desimone, L. M., Porter, A. C., Garet, M. S., Yoon, K. S., \& Birman, B. F. (2002). Effects of professional development on teachers' instruction: Results from a three-year longitudinal study. Educational Evaluation and Policy Analysis, 24(2), 81-112. https://doi.org/10.3102/01623737024002081

Eroğlu, M., \& Özbek, R. (2020). Etkili öğretmenlerin mesleki gelişimi. Dicle Üniversitesi Ziya Gökalp Ĕgitim Fakültesi Dergisi, 1(37), 73-92. http://dx.doi.org/10.14582/DUZGEF.2020.142

Edwards, A. R., Sandoval, C., \& McNamara, H. (2015). Designing for improvement in professional development for community college developmental mathematics faculty. Journal of Teacher Education, 66(5), 466-481. https://doi.org/10.1177/0022487115602313

Evans, L. (2014). Leadership for professional development and learning: enhancing our understanding of how teachers develop. Cambridge Journal of Education, 44(2), 179-198. https://doi.org/10.1080/0305764X.2013.860083

Eyecisoy, H. O. (2014). Sosyal bilgiler öğretmenlerinin, hizmet içi eğitim programlarına ilişkin görüşleri (Denizli İli Örneği). (Yayınlanmamış yüksek lisans tezi). Pamukkale Üniversitesi Eğitim Bilimleri Enstitüsü, Denizli.

Garet, M. S., Porter, A. C., Desimone, L., Birman, B. F., \& Yoon, K. S. (2001). What makes professional development effective? Results from a national sample of teachers. American Educational Research Journal, 38(4), 915-945. https://doi.org/10.3102/00028312038004915

Goe, L., \& Stickler, L.M. (2008). Teacher quality and student achievement: making the most of recent research. Washington, D.C.: National Comprehensive Center for Teacher Quality. 
Gomez, K., Gomez, L. M., Rodela, K. C., Horton, E. S., Cunningham, J., \& Ambrocio, R. (2015). Embedding language support in developmental mathematics lessons: Exploring the value of design as professional development for community college mathematics instructors. Journal of Teacher Education, 66(5), 450-465. https://doi.org/10.1177/0022487115602127

Glover, D., \& Law, S. (2005). Managing professional development in education. London, UK: Routledge Falmer.

Guskey, T. (2002). Professional development and teacher change. Teachers and Teaching: Theory and Practice, 8, 381-391. https://doi.org/10.1080/135406002100000512

Günel, M., \& Tanrıverdi, K. (2014). Dünya'da ve Türkiye'de hizmetiçi eğitimler: Kurumsal ve akademik hafıza (kayıpları) mı. Eğitim ve Bilim,39(175), 73-94. http://dx.doi.org/10.15390/EB.2014.2949

Henderson, M. (2007). Sustaining online teacher professional development through community design. Campus-Wide Information Systems, 24(3), 162-173. https://doi.org/10.1108/10650740710762202

Higgins, J., \& Parsons, R. (2009). A successful professional development model in mathematics: A system-wide New Zealand case. Journal of Teacher Education,60(3), 231-242. https://doi.org/10.1177/0022487109336894

James, M., \& McCormick, R. (2009). Teachers learning how to learn. Teaching and Teacher Education, 25(7), 973-982. https://doi.org/10.1016/j.tate.2009.02.023

Keung, C. C. (2009). Revitalizing teacher leadership via bureaucratic-professional practices: A structural equation model. The Asia-Pacific Education Researcher, 18(2), 283-295. https://doi.org/10.3860/taper.v18i2.1329

Korthagen, F. (2017). Inconvenient truths about teacher learning: Towards professional development 3.0. Teachers and Teaching, 23(4), 387-405. https://doi.org/10.1080/13540602.2016.1211523

Korthagen, F. A. J., Kim, Y. M., \& Greene, W. L. (Eds.). (2013). Teaching and learning from within: A core reflection approach to quality and inspiration in education. New York, NY: Routledge.

Kriek, J., \& Grayson, D. (2009). A holistic professional development model for South African physical science. London: Prentice Hall.

Kulaz, E. (2013). İlkokul öğretmenlerinin kendilerine yönelik hizmetiçi eğitim uygulamalarının koşulları ve verimliliği hakkındaki görüşleri. (Yayınlanmamış yüksek lisans tezi). Yeditepe Üniversitesi Sosyal Bilimler Enstitüsü, İstanbul.

Lawrence, C. A., \& Chong, W. H. (2010). Teacher collaborative learning through the lesson study: Identifying pathways for instructional success in a Singapore high school. Asia Pacific Education Review, 11(4), 565-572. https://doi.org/10.1007/s12564-010-9103-3

Macià, M., \& García, I. (2016). Informal online communities and networks as a source of teacher professional development: A review. Teaching and Teacher Education, 55, 291-307. https://doi.org/10.1016/j.tate.2016.01.021

Merriam, S. B., (2009). Qualitative research: A guide to design and implementation. San Francisco, CA: John Wiley \& Sons.

Mitchell, R. (2013). What is professional development, how does it occur in individuals, and how may it be used by educational leaders and managers for the purpose of school improvement? Professional Development in Education, 39(3), 387-400. https://doi.org/10.1080/19415257.2012.762721

Neil, P., \& Morgan, C. (2003). Continuing professional development for teachers. From introduction to senior management. London, UK: Kogan Page. 
Opfer, V. D., \& Pedder, D. (2011). The lost promise of teacher professional development in England. European Journal of Teacher Education, 34(1), 3-24. https://doi.org/10.1080/02619768.2010.534131

Postholm, M. B. (2012). Teachers' professional development: a theoretical review. Educational Research, 54(4), 405-429. https://doi.org/10.1080/00131881.2012.734725

Quick, H. E., Holtzman, D. J., \& Chaney, K. R. (2009). Professional development and instructional practice: Conceptions and evidence of effectiveness. Journal of Education for Students Placed at Risk, 14(1), 45-71. https://doi.org/10.1080/10824660802715429

Rockoff, J. E. (2004). The impact of individual teachers on student achievement: Evidence from panel data. The American Economic Review, 94(2), 247-252. http://doi.org/ $10.1257 / 0002828041302244$

Sales, A., Traver, J. A., \& García, R. (2011). Action research as a school-based strategy in intercultural professional development for teachers. Teaching and Teacher Education, 27(5), 911-919. https://doi.org/10.1016/j.tate.2011.03.002

Sancar, R., Atal, D., \& Deryakulu, D. (2021). A new framework for teachers' professional development. Teaching and Teacher Education, 101, 103305. https://doi.org/10.1016/j.tate.2021.103305

Soine, K. M., \& Lumpe, A. (2014). Measuring characteristics of teacher professional development. Teacher Development, 18(3), 303-333. https://doi.org/10.1080/13664530.2014.911775

Sutherland, L., Howard, S., \& Markauskaite, L. (2010). Professional identity creation: Examining the development of beginning preservice teachers' understanding of their work as teachers. Teaching and Teacher Education, 26(3), 455-465. https://doi.org/10.1016/j.tate.2009.06.006

Timperley, H., Wilson, A., Barrar, H., \& Fung, I. (2007). Teacher professional learning and development: Best evidence synthesis iteration. Wellington, New Zealand: Ministry of Education.

TsoTeTsi, C. T., \& Mahlomaholo, S. M. (2013). Teacher professional development programmes: What is missing?. Journal of Educational Studies, 12(1), 89-102.

Walter, C., \& Briggs, J. (2012). What professional development makes the most difference to teachers. Oxford, UK: Oxford University Press.

Wang, F. Y. (2018). An expert EFL reading teacher's readers club: reader identity and teacher professional development. European Journal of Teacher Education, 41(4), 517-528. https://doi.org/10.1080/02619768.2017.1416084

Wei, R.C., Darling-Hammond, L., Andree, A., Richardson, N., \& Orphanos, S. (2009). Professional learning in the learning profession: A status report on teacher development in the U.S. and abroad. Dallas, TX: National Staff Development Council.

Yoon, K. S., Duncan, T., Lee, S. W. Y., Scarloss, B., \& Shapley, K. L. (2007). Reviewing the evidence on how teacher professional development affects student achievement (Issues \& Answers Report, REL 2007-No. 033). Washington, DC: U.S. Department of Education, Institute of Education Sciences, National Center for Education Evaluation and Regional Assistance, Regional Educational Laboratory Southwest. https://ies.ed.gov/ncee/edlabs/regions/southwest/pdf/rel_2007033.pd adresinden 02.07.2020 tarihinde erişilmiştir.

\section{Extended Abstract}

\section{Introduction}

Enhancing the teachers' professional quality in Turkey, the Ministry of National Education has been cooperating to conduct new projects with other institutions and organizations. Considering that the quality of the achievement of the student largely on the quality of the teacher, it is very important for 
researchers, policymakers, and practitioners to understand the factors affecting the quality of a teacher's learning (Soine \& Lumpe, 2014). Many researchers agree with that the educational quality equals with the teachers' quality (Korthagen, 2017; Korthagen et al., 2013; TsoTeTsi \& Mahlomaholo, 2013; Yoon, Duncan, Lee, Scarloss, \& Shapley, 2007). Non-inclusive education policies unsupported by its practitioner have often failed in the past, so nowadays, the policies to support permanently learning teachers are needed (Collinson et al., 2009). One of the biggest problems preventing the teachers' professional development is the applications not focusing on situation/context and only transferring knowledge by an expert (DeMonte, 2013). Similarly, in Turkey, it is possible to encounter many professional development activities far from focusing on teachers' self-improvement regarding real classrooms and school context. We designed this research with the idea that it is necessary to descriptively analyze this situation.

\section{Purpose}

In this study, we aim to reveal the contents and limits of teachers' professional development in our country by examining the theses in the teacher training literature. The research questions examined for this purpose are given below:

1. What are the participants profiles of conducted theses in teacher education?

2. What is the duration of conducted theses in teacher education?

3. Which subject areas are centered in conducted theses in teacher education?

4. What are the main purposes/objectives addressed in these research processes?

5. Which data collection tools/methods were used for these research purposes?

\section{Method}

The basic interpretative design, one of the qualitative research methods, was used in the study. Document analysis was used as a qualitative data analysis method. While collecting the data, first of all, the titles of the theses in the National Thesis Center of the Council of Higher Education were scanned by using the keyword "professional development", and a total of 112 postgraduate theses were reached. Among these theses, 98 theses whose subject is "education and training", and which are open to access, were examined in total. The data were analyzed according to the themes created by the researchers. After coding, the VOSviewer program was used to reveal the network of patterns and relations between themes.

\section{Findings}

It is noteworthy that some variables have very complex relationships with each other in professionaldevelopment oriented theses. Among these variables, "master's degree", "0-1 week", "survey at the beginning of the process", "determine the situation" were the most remarkable variables. Although these variables attract the most attention in research, there are studies that take place for many different purposes with different processes. According to the findings, almost all of the studies (82.7\%) were only focused on teachers. In addition, the number of studies with more than 50 participants was quite limited. It was astonishing that there is almost no number of studies examining other stakeholders, such as school administrators, teacher candidates, government officials, and experts together. Another important finding obtained is that more than half of the examined theses took place in less than a week (57\%) and mostly in English (32\%) and Primary Education (20\%). 43\% of the research were carried out in order to determine the situation and $18 \%$ to improve teaching skills. Research conducted to design, implement and evaluate the professional development process constitute only $17 \%$ of all research. It was seen that most of the theses used case study, survey and mixed method. And the data were collected through surveys, interviews and observations conducted at the beginning of the process.

\section{Discussion and Conclusion}

Professional development is a process that takes place in teachers' content knowledge, pedagogy knowledge, professional skills, management knowledge or personal fields. According to many studies in the literature, this process is directly related to the success of students, the effectiveness of the education-training process, and the quality of the education system (see Darling-Hammond, 2000; Goe \& Stickler, 2008; Rockoff, 2004). It is noteworthy that professional development, which is so important in the education and training, has not been examined in depth and long-term in all dimensions in the 
theses in our country. Therefore, research in our country should be reviewed once more in terms of quality, not quantity. It is clear that in-depth research is needed, especially focusing on planning, implementation and evaluation processes. Another important dimension at this point is related to the duration of the studies. Birman, Desimone, Porter, and Garet (2000) argue that longer-term professional development will give teachers the opportunity to engage in more active learning and engage with classroom practice. Based on all these, it is clear that long-term longitudinal studies focusing on the relationships between teacher's learning, change and ultimately student learning are needed. Effective teaching is unlikely to happen by accident. Teachers need to see and be persuaded by the results of good and effective professional development processes. It is important to make changes in teachers' attitudes and beliefs along with classroom practices in the professional development process (Guskey, 2002). It is thought that this process should be carried out with applications, repetitions, discussions, collaborations, monitoring, feedback, support and distribution. In doing so, online environments, online coaching, learning communities can be encouraged to support and monitor teachers' learning and teachers' professional development. Thus, more accessibility, continuity and support can be provided.

* Bu çalışmada bulunan yazarlar çalışmaya ortak katkı sağlamışlardır. 